\title{
Effect of Atmospheric Temperature, Relative Humidity and Rainfall on Disease Development of Alternaria alternata Causing Alternaria Leaf Spot and Fruit Rot of Chilli under Natural Conditions
}

\author{
Manjul Pandey ${ }^{1 *}$, P.K. Dwivedi ${ }^{2}$, R.P. Mishra ${ }^{3}$ and Mukesh Srivastava ${ }^{3}$ \\ ${ }^{1}$ Krishi Vigyan Kendra, Banda, Banda University of Agriculture and Technology, \\ Banda-210001(UP), India \\ ${ }^{2}$ Krishi Vigyan Kendra, Raisen (MP), India \\ ${ }^{3}$ Department of Plant Pathology, C. S. Azad University of Agriculture \& Technology, \\ Kanpur-208002, India \\ *Corresponding author
}

A B S T R A C T

Ke y w ords

Chilli (Capsicum annuum),

Epidemiology,

Alternaria

alternata, Leaf spot,

fruit rot

Article Info

Accepted:

17 December 2018

Available Online:

10 January 2019
The data correlated regarding the effect of atmospheric temperature, relative humidity and rainfall on disease development during 2002-03 and 2003-04 revealed that, moderate relative humidity accompanied by nearly moderate temperature favoured disease development in both the years. The maximum disease development was recorded in the second fortnight of November during both the years. The average maximum and minimum temperatures and relative humidities were $29.7^{\circ} \mathrm{C}, 13.6^{\circ} \mathrm{C}$ and $87.5,39.2$ per cent, respectively during 200203 , whereas during 2003-04 average maximum and minimum temperature were $34.0^{\circ} \mathrm{C}$ and $15.4{ }^{\circ} \mathrm{C}$, respectively with average maximum and minimum relative humidities of 73.3 and 45.2 per cent, which led to maximum disease development. The rainfall in January led to rise in relative humidity and fall in atmospheric temperature hampered the disease development.

\section{Introduction}

Chilli (Capsicum annuum L.) is used as condiment as well as vegetable in every household of India. It has an important role in our daily diet. The fruits of chillies are used to increases the palatability and taste of cooked food and vegetable chilli is used to flavour soups, stews and sauces. The pickle of chillies is preferred by the masses. It is used in every vegetarian as well as non-vegetarian diet of the world. India is the major producer and exporter of chillies and their products to various countries including Abudhabi, Australia, Canada, Japan, U.S.A. and U.K. (Anonymous, 1992). According to Peter et al., (2004), in India, chillies are grown or cultivated in an area of 9.65 lakh ha with the 
production of 10.75 lakh tonnes. This contributes 35.5 per cent and 31.6 per cent, respectively, to the total area and production from all spices. In India, almost all the states cultivate chillies. However, Uttar Pradesh, Madhya Pradesh, Tamil Nadu, Andhra Pradesh, Karnataka, Punjab, Bihar, Maharashtra, Gujarat are the major chilli producers. In Uttar Pradesh, chillies are grown in 20,900 hectares with a total annual production of 16,400 tonnes. Chillies are the best and the cheapest source of vitamin $\mathrm{C}$ and A. The green chillies also contain rutin $\left(\mathrm{C}_{27} \mathrm{H}_{30} \mathrm{O}_{16}\right)$, which has specific medicinal value (Purseglove, 1977). The pungency of chilli is due to an alkaloid, "Capsaicin (C ${ }_{18} \mathrm{H}_{27} \mathrm{NO}_{3}$ )." The red colour in fruit at the ripening stage is due to the pigment Capsanthin (Nath, 1969). Chilli is valued throughout the world for pungency. The pungent principle of red pepper consists of a mixture of seven closely related allyl vanillyamides named Capsaicinoides, which are separated by solvent extraction of the dried fruits and the subsequent removal of the solvent (Tiwari, 1990; Govindrajan, 1985; Maya, 1975).

\section{Materials and Methods}

To find out the effects of atmospheric temperature, relative humidity and rainfall on disease development, a highly susceptible chilli variety 'Chaman' was sown in the field. Recommended doses of fertilizers and cultural practices were used and irrigation were applied whenever necessary. The data on disease development were recorded every 15 days of interval during 2002-2003 and 20032004. The weather data also recorded during the crop period and correlated with the disease development.

\section{Results and Discussion}

Atmospheric temperature, relative humidity and rainfall play a very important role in disease development. Therefore, it was felt desirable to study the role of these factors in the epidemiology of Alternaria leaf spot and fruit rot of chilli by the technique described in "Material and Methods'. The disease intensity under natural conditions was recorded at fortnightly intervals on the crop grown at vegetable Research Farm, Kalyanpur Kanpur.

The prevailing atmospheric temperature, relative humidity and rainfall were noted from the observatory installed in the vicinity and correlated with disease development and necessary observations were taken (Table 1, Fig. 1). The results summarized in Table 1 reveal that environmental factors, viz., atmospheric temperature, relative humidity and rainfall play significant role in disease intensity.

There is fairly good correlation between atmospheric temperature, relative humidity and rainfall and disease intensity. The disease appeared in the first fortnight of July which gradually increased upto first fortnight November and thereafter, there was a decline in disease intensity with lowering down of temperature and relative humidity upto the month of January.

Maximum disease intensity (36.9\%) during year 2002-03 and (36.5\%) during 2003-04, in first fortnight of November, when the maximum and minimum atmospheric temperature varied between $29.7-13.6^{\circ} \mathrm{C}$ in the year $2002-03$ and $24.0-15.4^{\circ} \mathrm{C}$ during year 2003-04, respectively and relative humidity varied upto 87.5-39.2 per cent (2002-03) a nd 73.3- 45.2 per cent (2003-04). However, there was no effect of rainfall on the disease development, as there was no rain during the said period. The minimum intensity (10.3 and 10.9 per cent) was observed in August when both the atmospheric temperature and the relative humidity were high, while in the month of January the disease intensity was observed low (29.3 and 28.1 per cent). 
Table.1 Effect of atmospheric temperature, relative humidity and rainfall on disease development under natural conditions

\begin{tabular}{|c|c|c|c|c|c|c|c|c|c|c|c|c|}
\hline \multirow[t]{5}{*}{ Period } & \multicolumn{4}{|c|}{ Average temperature $\left({ }^{\circ} \mathrm{C}\right)$} & \multicolumn{4}{|c|}{ Average relative humidity $(\%)$} & \multirow{2}{*}{\multicolumn{2}{|c|}{$\begin{array}{c}\text { Average } \\
\text { rainfall }(\mathbf{m m})\end{array}$}} & \multirow{2}{*}{\multicolumn{2}{|c|}{$\begin{array}{c}\text { Disease intensity } \\
(\%)\end{array}$}} \\
\hline & & & & & & & & & & & & \\
\hline & \multicolumn{2}{|c|}{ 2002-03 } & \multicolumn{2}{|c|}{ 2003-04 } & \multicolumn{2}{|c|}{ 2002-03 } & \multicolumn{2}{|c|}{ 2003-04 } & 2002- & 2003- & 2002-03 & 2003-04 \\
\hline & \multirow[b]{2}{*}{ Max. } & \multirow[b]{2}{*}{ Min. } & \multirow[b]{2}{*}{ Max. } & \multirow[b]{2}{*}{ Min. } & \multirow[b]{2}{*}{ Max. } & \multirow[b]{2}{*}{ Min. } & \multirow[b]{2}{*}{ Max. } & \multirow[b]{2}{*}{ Min. } & \multirow[t]{2}{*}{$\mathbf{0 3}$} & & & \\
\hline & & & & & & & & & & & & \\
\hline & & & & & & & & & & & & \\
\hline First fortnight of July & 39.6 & 30.8 & 31.4 & 21.6 & 60.6 & 39.5 & 83.3 & 57.3 & 0.0 & 15.6 & 10.3 & 10.9 \\
\hline Second fortnight of & 40.4 & 30.4 & 31.8 & 20.8 & 70.8 & 55.1 & 91.2 & 64.8 & 1.7 & 8.5 & 11.8 & 12.4 \\
\hline \multicolumn{13}{|l|}{ July } \\
\hline First fortnight of & 33.1 & 26.9 & 31.2 & 19.9 & 87.4 & 71.8 & 91.7 & 65.0 & 13.3 & 5.2 & 15.1 & 15.0 \\
\hline \multicolumn{13}{|l|}{ August } \\
\hline Second fortnight of & 34.4 & 27.5 & 34.0 & 24.1 & 99.2 & 78.8 & 92.1 & 73.8 & 4.6 & 2.4 & 19.2 & 18.9 \\
\hline \multicolumn{13}{|l|}{ August } \\
\hline First fortnight of & 30.3 & 24.4 & 32.0 & 21.5 & 90.3 & 79.6 & 93.3 & 88.1 & 26.0 & 30.3 & 21.9 & 24.7 \\
\hline \multicolumn{13}{|l|}{ September } \\
\hline Second fortnight of & 32.3 & 23.1 & 31.7 & 24.3 & 86.1 & 62.6 & 91.0 & 83.4 & 0.0 & 5.6 & 25.3 & 26.6 \\
\hline \multicolumn{13}{|l|}{ September } \\
\hline First fortnight of & 33.3 & 21.8 & 33.5 & 20.8 & 78.9 & 48.4 & 82.8 & 60.7 & 0.1 & 0.0 & 28.7 & 30.3 \\
\hline \multicolumn{13}{|l|}{ October } \\
\hline Second fortnight of & 33.9 & 20.1 & 34.5 & 20.3 & 88.6 & 44.2 & 89.6 & 55.3 & 0.1 & 0.0 & 31.2 & 34.0 \\
\hline \multicolumn{13}{|l|}{ October } \\
\hline First fortnight of & 29.7 & 13.6 & 34.0 & 15.4 & 87.5 & 39.2 & 73.3 & 45.2 & 0.0 & 0.0 & 36.9 & 36.5 \\
\hline \multicolumn{13}{|l|}{ November } \\
\hline Second fortnight of & 27.9 & 15.1 & 27.1 & 18.0 & 84.5 & 36.0 & 79.1 & 47.6 & 0.0 & 0.0 & 35.1 & 36.0 \\
\hline \multicolumn{13}{|l|}{ November } \\
\hline First fortnight of & 23.3 & 16.2 & 26.7 & 11.1 & 85.0 & 32.6 & 83.8 & 57.4 & 0.0 & 0.0 & 33.5 & 32.8 \\
\hline December & & & & & & & & & & & & \\
\hline Second fortnight of & 25.1 & 7.9 & 20.4 & 9.0 & 95.3 & 50.3 & 86.6 & 50.6 & 0.0 & 1.8 & 30.2 & 28.5 \\
\hline December & & & & & & & & & & & & \\
\hline First fortnight of & 13.4 & 3.0 & 16.6 & 6.2 & 95.6 & 77.9 & 85.0 & 79.2 & 0.8 & 0.0 & 29.3 & 28.1 \\
\hline January & & & & & & & & & & & & \\
\hline & & & & & & & & & & & & \\
\hline
\end{tabular}


Fig.1 Effect of environmental factors on disease development
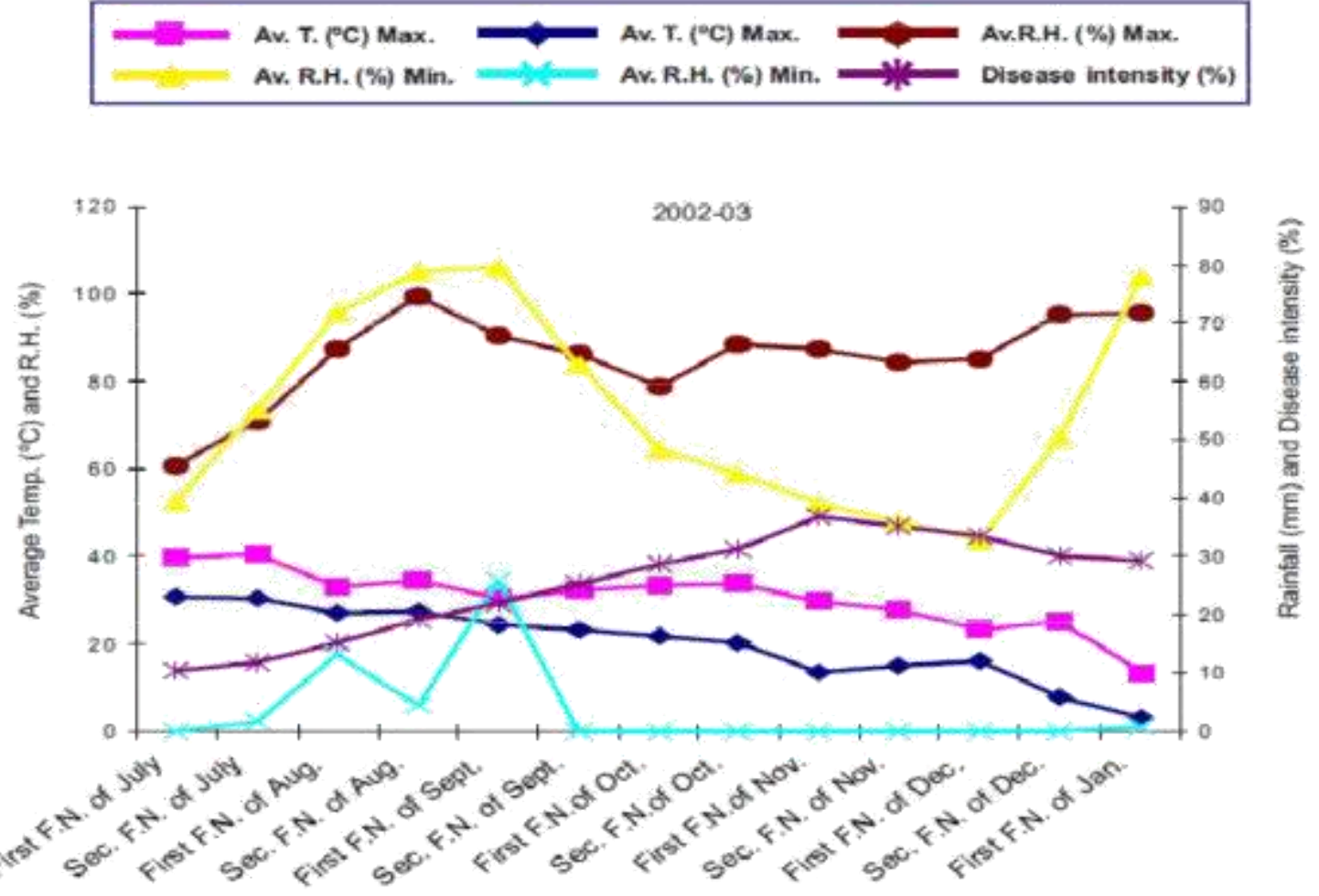

2003-04

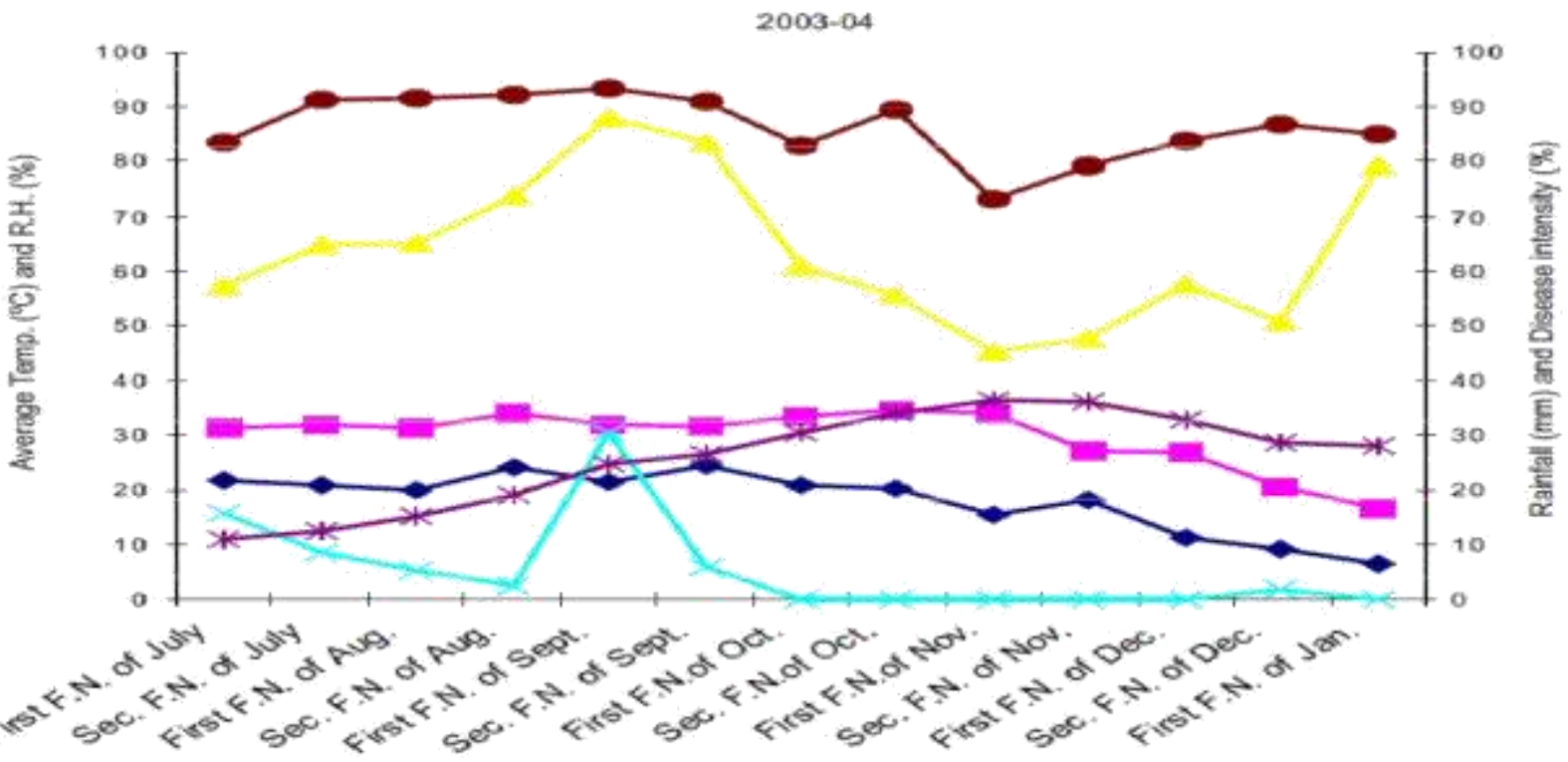

The reason being instead of increase in relative humidity, the lowering down of atmospheric temperature continues to lower down disease intensity and the rainfall does not show significant any effect on it. Thus, it may be concluded that in general the maximum and minimum temperature and relative humidity have an impact on disease development, where the high temperature together with high humidity keeps the disease 
intensity low, whereas low temperature together with comparatively low humidity favour high disease development. The maximum disease development was recorded in the first fortnight of November during 2002-03 and 2003-04. The average maximum and minimum temperatures and average maximum and minimum relative humidities were $29.7^{\circ} \mathrm{C}$ and $13.6^{\circ} \mathrm{C}$ and 87.5 per cent and 39.2 per cent, respectively during 2002-03, whereas during 2003-04 average maximum and minimum temperatures were $34.0^{\circ} \mathrm{C}$ and $15.4^{\circ} \mathrm{C}$, respectively with average maximum and minimum relative humidities of 73.3 and 45.2 per cent led to maximum disease development. The rainfall in January led to rise in relative humidity and fall in atmospheric temperature hampered disease development. No work on the epidemiology of this disease has been done before. However, Ghewande (1986) found that temperature between $25^{\circ} \mathrm{C}$ to $29^{\circ} \mathrm{C}$ and relative humidity of 87 per cent were more favouable for the development of Alternaria leaf spot of ground nut incited by Alternaria alternata. Patel and Patel (1991) reported that temperature range of $25-40^{\circ} \mathrm{C}$ and high relative humidity favoured the development of tomato rots in open market caused by Alternaria alternata. Singh and Majumdar (2000) observed that Alternaria alternata caused major rot disease in pomegrante. The rotting was maximum at $25^{\circ} \mathrm{C}$ temperature and 90 per cent relative humidity.

\section{References}

Anonymous (1992). Estimated export of chilli from India during 1991. Spice India, 5(1): 20.

Ghewande, M.P. (1986). Epidemiology of foliar diseases: Annual Report National Research Center for Groundnut, Junagarh, p. 30-31.

Govindrajan, V.S. (1985). Capsicum production technology, chemistry and quality. Part II. Processed products standards, world production and trade. C.R.C. Critical Review in Nut. 23(3): 207-288.

Maya, J.A. (1975). Capsicum. C.R.C. Critical Review in Food, Sci., Nut., 6(2) : 177-193.

Nath, P. (1969). Vegetables for the Tropical Region. Indian Council of Agricultural Research, New Delhi, Book Series No. 2.

Patel, R.B. and Patel, G.S. (1991). Post harvest diseases of tomato and their control. Indian. J. Agric. Res., 25: 173-176.

Peter, K.V; Nybe, E.V. and Thanuja, T.V. (2004). Future prospects. Survey of Indian Agriculture. The Hindu. 56-59 pp.

Purseglove, J.W. (1977). Tropical Crops. Dicotyledons I \& II. Longman, London, U.K.135-136 pp.

Singh, Jitendra and Majumdar, V.L. (2000). Epidemiology and management of post harvest disease of Pomegranate caused by Alternaria alternata. Indian J. Mycol. Pl.

Tiwari, V.P. (1990). Development of high capsaicin chillies (Capsicum annuum L.) and their implications for the manufacture of export products. J. Plant Crops. 18 (1): $1-13$.

\section{How to cite this article:}

Manjul Pandey, P.K. Dwivedi, R.P. Mishra and Mukesh Srivastava. 2019. Effect of Atmospheric Temperature, Relative Humidity and Rainfall on Disease Development of Alternaria alternata Causing Alternaria Leaf Spot and Fruit Rot of Chilli under Natural Conditions. Int.J.Curr.Microbiol.App.Sci. 8(01): 2860-2864.

doi: https://doi.org/10.20546/ijcmas.2019.801.300 